Artikel Penelitian

\title{
Terapi Infusa Pekat Buah Pare (Momordica charantia L.) terhadap Kadar Glukosa Darah dan SOD pada Ginjal Tikus DM Tipe 1
}

\author{
Nuraeni Uswatun Hasanah, Hafidatul Hasanah, Himmatul Baroroh*
}

Jurusan Kimia, Fakultas Sains dan Teknologi, Universitas Islam Negeri Maulana Malik Ibrahim, Malang, Indonesia, 65144

\section{INFO ARTIKEL}

\section{Riwayat Artikel}

Direvisi 11 November 2018

Diterima 22 Desember 2018

Tersedia online 30 Desember 2018

${ }^{*}$ Email penulis korespondensi:

himmatul.b@gmail.com

\section{ABSTRAK}

Bitter melon (Momordica charantia L.) is one of the Cucurbitaceae families which is useful as traditional antidiabetic medicine. Diabetes mellitus (DM) is an autoimmune disease indicated by increasing blood sugar levels. The aim of this study to determine the effect of concentrated infusions therapy of bitter melon fruit on blood glucose levels and SOD activity in three diabetic levels (low, medium, acute) in DM Type 1 of rat kidney. The doses of therapy used were $0.15,0.30,0.45,0.60,0.80$ and $1 \mathrm{~mL} / 200 \mathrm{~g}$ body weight (BW). Blood sugar level was measured using enzymatic (glucose oxidase) method and SOD activity using NBT (Nitroblue tetrazolium) test. The results showed that the concentrated infusions therapy of bitter melon fruit was able to decrease blood glucose levels and increase the SOD activity of DM 1 in the rat kidney. The average ability of the therapy to reduce DM in low, medium, and acute level was $87.21,84.5$ and $55,56 \%$, respectively. In $0.3 \mathrm{~mL} / 200 \mathrm{~g} \mathrm{Bw}$ dose, concentrated infusions therapy of bitter melon fruit reduced blood sugar level to all diabetes levels. The average value of concentrated infusions therapy of bitter melon fruit in increasing SOD activity was $144.76 \%$.

Keywords: Diabetes mellitus, infuse, SOD (superoxide dismutase), bitter melon fruit (Momordica charantia L.)

Buah pare (Momordica charantia L.) merupakan salah satu keluarga Cucurbitaceae yang bermanfaat sebagai obat tradisional, salah satunya untuk antidiabetes. Diabetes mellitus (DM) merupakan salah satu penyakit autoimun yang ditandai dengan meningkatnya kadar gula darah (KGD). Penelitian ini bertujuan untuk mengetahui pengaruh terapi infusa pekat buah pare terhadap kadar glukosa darah dan SOD pada tiga tingkat diabetes yaitu ringan, sedang dan akut pada ginjal tikus DM tipe 1 . Dosis yang digunakan yakni 0,$15 ; 0,30$; 0,$45 ; 0,60 ; 0,80$; dan $1 \mathrm{~mL} / 200 \mathrm{~g} \mathrm{BB}$. KGD diiukur dengan metode enzimatik (glukosa oksidase) dan aktivitas SOD diukur dengan uji NBT (Nitroblue tetrazolium). Hasil penelitian menunjukkan terapi infusa pekat buah pare berpengaruh terhadap penurunan kadar glukosa darah dan peningkatan kadar SOD pada ginjal tikus DM 1. Kemampuan rata-rata terapi dalam menurunkan DM tingkat ringan, sedang, dan akut masing-masing sebesar 87,$21 ; 84,5$ dan $55,56 \%$. Pada dosis $0,3 \mathrm{~mL} / 200 \mathrm{~g} \mathrm{BB}$, terapi infusa pekat buah pare mampu menurunkan KGD terhadap seluruh tingkat DM. Kemampuan rata-rata infusa pekat buah pare dalam meningkatkan kadar SOD sebesar $144,76 \%$.

Kata Kunci: Diabetes mellitus, infusa, SOD (superoksida dismutase), buah pare (Momordica charantia L.) 


\section{Pendahuluan}

Diabetes mellitus (DM) adalah penyakit yang ditandai oleh gula darah yang tinggi karena adanya gangguan produksi sekresi insulin atau resistensi insulin. Penyakit ini sangat penting untuk diperhatikan karena jumlah penderitanya semakin meningkat setiap tahunnya. Saat ini diduga secara global jumlah penderita diabetes adalah 200 juta [1]. DM merupakan penyakit kronis yang dapat menimbulkan komplikasi, diantaranya nefropatik diabetik yaitu gangguan ginjal akibat tingginya Kadar Gula Darah (KGD) dalam tubuh. Nefropatik diabetik ini menjadi penyebab utama gagal ginjal terminal [2]. Oleh karena itu, penting untuk menjaga KGD penderita DM pada tingkat normal untuk mencegah terjadinya gagal ginjal. Salah satu penyebab gagal ginjal adalah terjadinya stres oksidatif.

Stres oksidatif terjadi karena adanya jumlah radikal bebas di dalam tubuh yang melebihi kapasitas tubuh untuk menetralkannya. Sementara, KGD yang konstan tinggi dalam tubuh merupakan pemicu terbentuknya radikal bebas dalam jumlah yang besar dan terus-menerus. Mekanisme pertahanan tubuh dalam mengatasi radikal bebas ini melibatkan salah satunya enzim superoksida dismutase (SOD) [3]. Radikal bebas merupakan senyawa yang dapat berada tersebar di seluruh organ tubuh, demikian juga SOD, merupakan enzim yang akan diproduksi oleh tubuh dimana terdapat sejumlah radikal bebas untuk dinetralkan.

SOD merupakan salah satu antioksidan endogen yang berperan penting dalam mengkatalisis radikal bebas anion superoksida $\left(\mathrm{O}_{2}{ }^{\circ}\right)$ menjadi hidrogen peroksida $\left(\mathrm{H}_{2} \mathrm{O}_{2}\right)$ dan molekul oksigen [4]. Terapi untuk menurunkan KGD pada penderita DM biasanya dengan menggunakan suntikan insulin dan obat antidiabetes oral lain. Akan tetapi, terapi ini memiliki efek samping seperti sakit kepala, pusing dan mual. Selain itu, terapi ini juga membutuhkan biaya yang mahal karena harus diberikan suntikan insulin secara kontinyu. Oleh karena itu, diperlukan suatu pengobatan alternatif yang harganya relatif murah dan khasiatnya tidak berbeda jauh dengan obat sintetik untuk terapi yang bersifat kontinyu. Salah satu alternatif pengobatan tersebut adalah penggunaan obat herbal dari buah pare (Momordica charantia L.) [5].

Buah pare mengandung senyawa kimia yang berkhasiat dalam pengobatan diantaranya saponin, flavonoid, polifenol, alkaloid, charantin, polipeptida-p dan tannin [6]. Salah satu khasiat buah pare yang telah diketahui secara tradisional adalah dapat menurunkan KGD. Khasiat antihiperglikemik ini sering diidentikkan dengan rasa pahit pada buah pare [7]. Beberapa penelitian yang telah dilakukan menunjukkan adanya aktivitas antihiperglikemik buah pare [8, 9]. Pratama [9] meneliti tentang terapi decokta buah pare untuk menurunkan KGD tikus DM. Hasilnya menunjukkan bahwa dosis $10 \mathrm{~mL} / 200 \mathrm{~g}$ BB decokta buah pare tidak mampu menurunan KGD secara signifikan, pada dosis tersebut ekstrak decokta hanya memiliki kemampuan $1 / 3$ dari Obat Hiperglikemia Oral $(\mathrm{OHO})$ glibenklamid. Kekurangefektifan terapi ini dimungkinkan terkait dengan kadar esktrak yang tidak mencukupi.

Pada penelitian ini akan dipelajari kemampuan terapi ekstrak infusa pekat buah pare dalam penurunkan. KGD dan peningkatan aktivitas SOD pada ginjal tikus DM tipe 1 akibat induksi aloksan. Penelitian ini menggunakan metode infusa untuk mengekstrak buah pare. Infusa adalah sediaan yang dibuat dengan mengekstraksi sampel nabati (simplisia) dengan air pada suhu $90^{\circ} \mathrm{C}$ selama 15 menit [10]. Metode infusa ini merupakan metode yang sederhana dengan menggunakan air sebagai pelarutnya. Pelarut ini lebih aman dan harganya terjangkau sehingga semua kalangan masyarakat dapat menggunakannya.

\section{Bahan dan Metode}

\subsection{Bahan}

Bahan yang digunakan terdiri atas buah pare lokal dengan umur buah 2,5 bulan setelah tanam yang dibuat dalam sediaan serbuk kering (simplisia), tikus putih (Rattus norvegicus) strain wistar jantan umur 2-3 bulan dengan berat \pm 200 g, aloksan (alloxan monohydrate), $\mathrm{NaCl}$ 0,9\%, alkohol, gluko strip DR, larutan standar SOD (konsentrasi 5, 10, 20, 40, 80, $160 \mathrm{U} / \mathrm{mL}$ ), larutan PBS, xantin, XOD (xantin oksidase), NBT (Nitroblue tetrazolium) dan akuades.

\subsection{Pembuatan Infusa Pekat Buah Pare}

Metode pembuatan infusa mengikuti standart dalam Farmakope Indonesia [10]. Infusa diberikan setiap hari selama 14 hari dalam keadaan segar. Infusa pekat dibuat dengan memasukkan 30 gram simplisia buah pare dalam $100 \mathrm{~mL}$ air dan dipanaskan dalam panci infusa. Panci dipanaskan di dalam penangas air selama 15 menit dihitung mulai suhu di dalam panci mencapai $90^{\circ} \mathrm{C}$, sambil sesekali diaduk. Penyaringan dilakukan selagi panas menggunakan kertas saring, setelah disaring ditambahkan air hingga volumenya $100 \mathrm{~mL}$.

\subsection{Persiapan Hewan Coba}

Penelitian ini menggunakan hewan coba tikus putih strain wistar jantan umur 2 bulan dengan berat badan awal 100130 gram. Kondisi tikus dalam keadaan sehat yang ditandai oleh gerakan aktif. Sebelum perlakuan, tikus dipelihara 
dalam kandang berukuran $20 \times 30 \times 40 \mathrm{~cm}$ yang diberi alas serbuk kayu dan anyaman kawat sebagai penutup atas kandang. Pemberian makan dan minum dilakukan setiap hari secara ad libitum selama 7 hari.

\subsection{Persiapan Tikus Diabetes Mellitus Hewan Coba}

Tikus dikondisikan diabetes dengan menginjeksikan aloksan pada daerah interperitonialnya dengan dosis 32 $\mathrm{mL} / 200 \mathrm{~g} \mathrm{BB}$ aloksan. Dosis aloksan tersebut mampu membuat tikus diabetes dengan cepat tanpa menyebabkan kematian [11]. Jumlah tikus yang digunakan adalah 32 ekor sebagai sampel. Empat ekor tikus diperlakukan sebagai kelompok normal (KN) tanpa injeksi aloksan dan tanpa terapi. Empat ekor tikus diperlakukan sebagai kelompok positif DM tanpa terapi (KP). Sisa tikus sejumlah 24 ekor diperlakukan sebagai kelompok terapi. Mula-mula tikus kelompok terapi dikondisikan menderita DM melalui induksi aloksan. Tikus terapi yang telah positif DM akan dikelompokkan menjadi 3 kelompok terapi (KT), yaitu Kelompok Terapi dengan tingkat DM ringan (DM ringan) dengan KGD 180-270 $\mathrm{mg} / \mathrm{dL}$, Kelompok Terapi dengan tingkat DM sedang (DM sedang) dengan KGD 271-359 mg/dL dan Kelompok Terapi dengan tingkat DM akut (DM akut) dengan KGD 360-600 mg/dL.

\subsection{Terapi Tikus SM dengan Infusa Buah Pare}

Terapi untuk tikus yang positif DM dengan infusa pekat buah pare pada kelompok terapi dilakukan secara oral (sonde) dengan dosis $0,15 \mathrm{~mL} / 200 \mathrm{~g} \mathrm{BB} ; 0,30 \mathrm{~mL} / 200 \mathrm{~g} \mathrm{BB} ; 0,45 \mathrm{~mL} / 200 \mathrm{~g} \mathrm{BB} ; 0,60 \mathrm{~mL} / 200 \mathrm{~g} \mathrm{BB} ; 0,80 \mathrm{~mL} / 200 \mathrm{~g} \mathrm{BB} ; 1$ $\mathrm{mL} / 200 \mathrm{~g}$ BB. Pemberian ekstrak dilakukan setiap hari selama 14 hari berturut-turut. Terapi tidak dilakukan pada kelompok tikus kontrol positif.

\subsection{Pengukuran Kadar Glukosa Darah}

Pengukuran kadar glukosa darah dilakukan dengan menggunakan metode enzimatik (glukosa oksidase) menggunakan glukometer. Pengambilan sampel darah dilakukan dengan cara tikus diletakkan pada sungkup, ekor tikus dipegang, diurut, dan diberi alkohol. Kemudian, ujung ekor dipotong sedikit sampai darah keluar, darah diambil, dan diteteskan pada strip glukotest. Hasil pengukuran kadar glukosa darah yang terbaca pada glukometer dicatat sebagai data.

\subsection{Uji Aktivitas SOD}

\subsubsection{Pengambilan Organ Ginjal}

Tikus dimatikan terlebih dahulu dengan cara dislokasi leher. Skalpel dan alat bedah disiapkan untuk membantu mengambil organ ginjal. Setelah mati, tikus diletakkan pada papan fiksasi dan ditata pada posisi ventral diatas. Ginjal diambil dan dicuci. Setelah itu, disimpan dalam wadah tertutup dan dingin dengan suhu $-70^{\circ} \mathrm{C}$ (diletakkan dalam freezer) untuk analisis selanjutnya.

\subsubsection{Analisis Aktivitas Enzim SOD}

Pengukuran aktivitas enzim SOD menggunakan metode NBT. Larutan standart superoksida dismutase dengan konsentrasi larutan 5, 10, 20, 40, 80, $160 \mathrm{U} / \mathrm{mL}$ digunakan untuk membuat kurva standar. Dimasukkan larutan xantin sebanyak $100 \mu \mathrm{L}$ dalam tabung mikro $2 \mathrm{~mL}$, ditambahkan xantin oksidase $100 \mu \mathrm{L}, 100 \mu \mathrm{L}$ NBT, $1600 \mu \mathrm{L}$ PBS pH 7,4 dan $100 \mu \mathrm{L}$ sampel ginjal yang setelah dihaluskan. Selanjutnya, campuran divortex selama 10 detik dengan kecepatan $2600 \mathrm{rpm}$, kemudian diinkubasi selama 30 menit dalam inkubator suhu $30^{\circ} \mathrm{C}$. Setelah itu, larutan dalam tabung mikro disentrifugasi selama 10 menit pada kecepatan 3500 rpm, diambil supernatannya dan dimasukkan kuvet, lalu diukur absorbansinya menggunakan spektofotometer pada panjang gelombang $580 \mathrm{~nm}$. Blanko yang digunakan adalah larutan PBS pH 7,4.

\section{Hasil dan Pembahasan}

\subsection{Ekstraksi Infusa Buah Pare}

Penelitian ini menggunakan metode infusa yaitu sediaan yang dibuat dengan mengektraksi simplisia dengan air pada suhu $90^{\circ} \mathrm{C}$ selama 15 menit. Akan tetapi jumlah simplisia yang digunakan tiga kali lebih besar dari standar metode pembuatan infusa dalam Farmakope Indonesia [10], yaitu sebanyak 30 gram simplisia. Infusa yang dihasilkan merupakan infusa pekat dengan karakteristik fisik berupa cairan kental berwarna kuning kecoklatan.

\subsection{Pengaruh Ekstrak Infusa Pekat Buah Pare terhadap KGD Tikus DM Tipe 1}

Pengukuran KGD dilakukan dengan metode enzimatik (glukosa oksidase) menggunakan glukometer. Pengambilan sampel darah diambil pada ujung ekor tikus. Hasil penghitungan KGD yang terbaca pada glucometer diperlihatkan pada Gambar 1. 


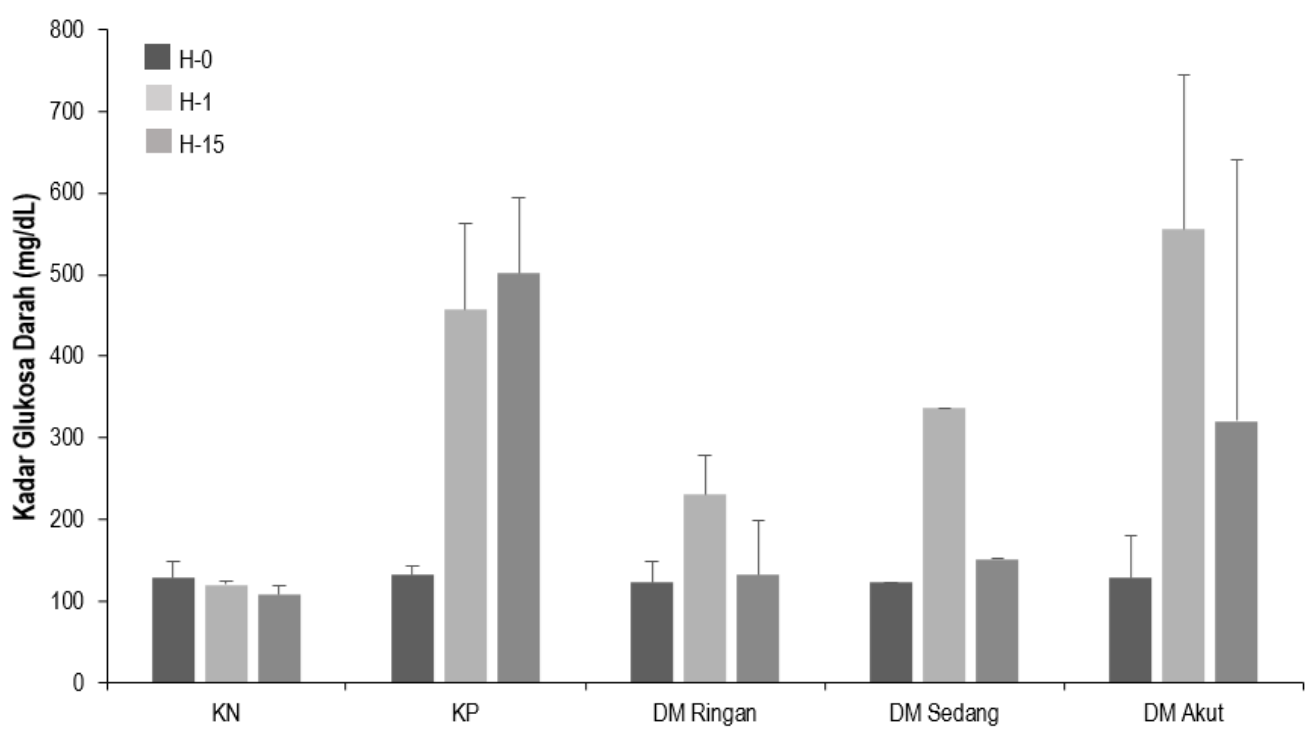

Gambar 1. Nilai Kadar Glukosa Darah (KDG) tikus pada hari ke-0, 1, dan 15. KN = Kelompok kontrol normal tanpa perlakuan, $\mathrm{KP}=$ Kelompok kontrol positif DM, $\mathrm{H}-\mathrm{O}=\mathrm{KGD}$ sebelum diinduksi aloksan, $\mathrm{H}-1=\mathrm{KGD}$ sesudah diinduksi aloksan, $\mathrm{H}-15=\mathrm{KGD}$ sesudah terapi.

Gambar 1 menunjukan KGD tikus yang sebelum $(\mathrm{H}-0)$ dan sesudah $(\mathrm{H}-1)$ diinduksi aloksan serta KGD tikus setelah diterapi infusa pekat buah pare $(\mathrm{H}-15)$ selama 14 hari. KGD seluruh tikus pada $\mathrm{H}-0$ yaitu dibawah $200 \mathrm{mg} / \mathrm{dL}$. Hal ini menunjukkan bahwa keadaan tikus masih dalam keadaan normal. Pada hari ke-1 tikus yang diinduksi aloksan mengalami peningkatan KGD. Aloksan menyebabkan tikus mengalami kenaikan KGD > $200 \mathrm{mg} / \mathrm{dL}$, hal ini menunjukkan bahwa tikus sudah mengalami diabetes. Peningkatan KGD ini disebabkan oleh induksi aloksan yang telah merusak sel $\beta$ Langerhans pankreas sehingga insulin tidak dapat diproduksi untuk menurunkan KGD.

Tikus pada kontrol normal (KN) memiliki kadar glukosa darah yang stabil dibawah $200 \mathrm{mg} / \mathrm{dL}$ sejak H-0 sampai H15 percobaan. Tikus pada kontrol positif (KP) mengalami peningkatan KGD selama percobaan. Adapun kontrol terapi mengalami perubahan penurunan yang signifikan untuk seluruh kelompok perlakuan pada seluruh dosis terapi.

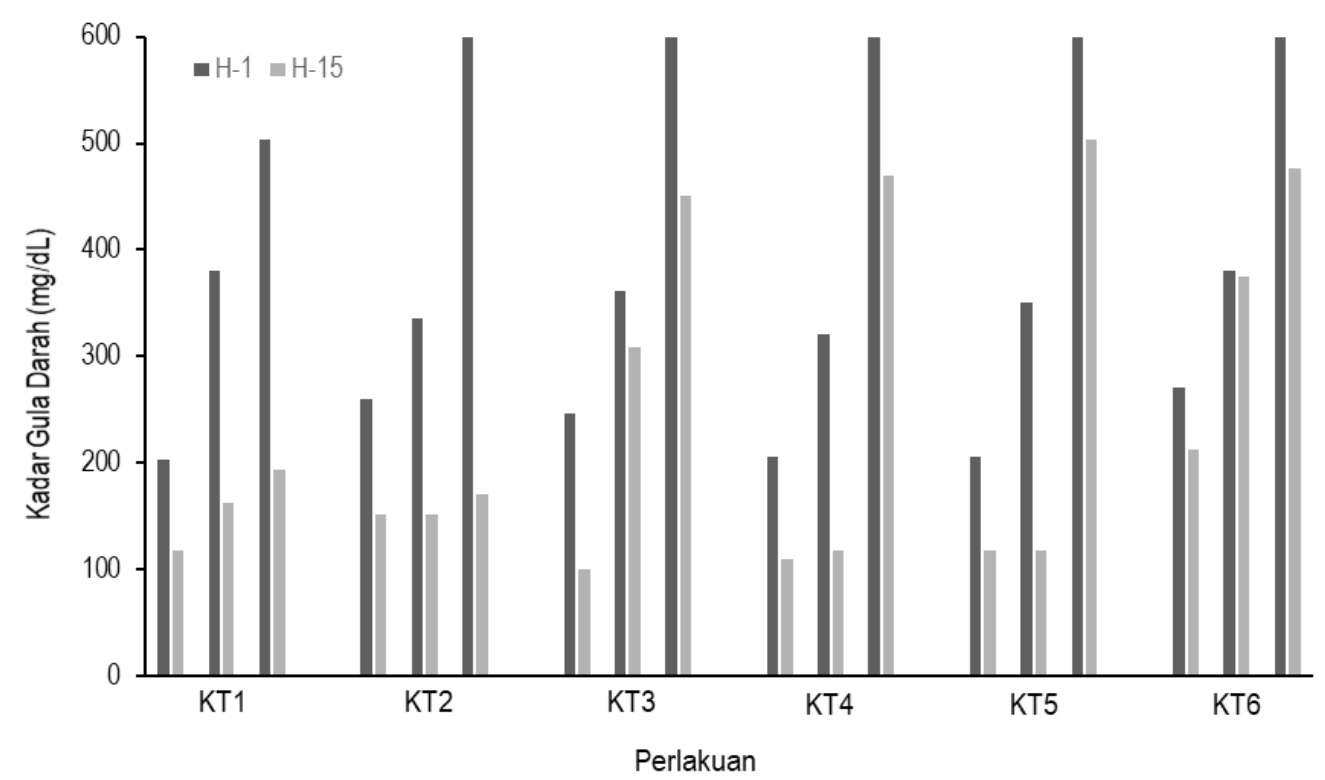

Gambar 2. KGD tikus yang diterapi infusa buah pare pada dosis yang diterapkan pada keadaan DM sebelum terapi (H-1) dan sesudah terapi $(\mathrm{H}-15)$. KT $1=$ dosis $0,15 \mathrm{~mL}, \mathrm{KT} 2=$ dosis $0,3 \mathrm{~mL}, \mathrm{KT} 3=$ dosis $0,45 \mathrm{~mL}, \mathrm{KT} 4=$ dosis $0,6 \mathrm{~mL}, \mathrm{KT} 5=$ dosis $0,8 \mathrm{~mL}, \mathrm{KT} 6=$ dosis $1 \mathrm{~mL}$.

Pada kelompok terapi dengan diabetes ringan (DM ringan) ekstrak infusa pekat buah pare dapat menurunkan KGD rata-rata sebesar $87,21 \%$, pada kelompok terapi dengan diabetes sedang (DM sedang) sebesar $84,5 \%$ dan pada kelompok terapi dengan diabetes akut (DM akut) sebesar 55,56\%. Pada diabetes ringan (DM ringan) didapat nilai 
kemampuan penurunan kadar glukosa darah dari terapi infusa yang tinggi dikarenakan dalam kondisi diabetes ringan kadar glukosa darah mudah diturunkan sedangkan pada diabetes akut (DM akut) nilainya rendah diduga terkait dengan proses metabolisme di tubuh tikus yang rendah yang ditunjukkan oleh keadaan fisik tikus yang sangat lemah sehingga kadar glukosa darah sulit untuk diturunkan.

Pengamatan lebih dalam pada penurunan KGD untuk setiap variasi dosis menunjukkan bahwa variasi dosis ternyata memberikan tingkat penurunan KGD yang beragam pada tikus DM tipe 1. Akan tetapi, hasil yang cukup menarik terlihat pada dosis 0,3 mL/200 g BB. Gambar 2 menunjukkan bahwa dosis 0,3 ml/200 g BB memiliki kemampuan menurunkan kadar glukosa darah untuk tingkat diabetes ringan (DM ringan), sedang (DM sedang) dan akut (DM akut) sehingga mencapai tingkat kadar glukosa darah normal yaitu dibawah $200 \mathrm{mg} / \mathrm{dL}$ setelah 14 hari terapi. Hal ini tidak diamati pada terapi dengan dosis yang lain.

Penurunan KGD diduga karena adanya senyawa aktif yang terdapat dalam buah pare yang berpotensi menurunkan kadar glukosa dalam darah tikus. Menurut Yuda, dkk [8], senyawa yang terdapat dalam buah pare (Momordica charantia L.) meliputi flavonoid, polipeptida-p, polifenol, saponin, tanin, dan alkaloid. Kandungan senyawa aktif dalam buah pare berperan sebagai antioksidan yang mampu menangkal adanya radikal bebas dalam tubuh, salah satunya adalah polipeptida-p. Polipeptida-p ini memiliki aktifitas hampir sama dengan insulin yaitu menstimulasi pengeluaran insulin pada pankreas. Senyawa ini diduga juga memiliki aktivitas sebagai penurunan kadar glukosa darah.

\subsection{Aktivitas Superoxide Dismutase (SOD) pada Ginjal Tikus DM Tipe 1}

Aktivitas enzim SOD dianalisis dalam organ ginjal dikarenakan hiperglikemia berhubungan dengan kerusakan jangka panjang dan kegagalan organ-organ terutama mata, ginjal, saraf, jantung dan pembuluh darah [12]. Menurut Wresdiyati [4], keadaan stres oksidatif menimbulkan penurunan aktivitas SOD pada ginjal. Stres oksidatif yang dipicu oleh keadaan hiperglikemik lanjut salah satunya menyebabkan nefropati. Nefropati diabetik adalah penyakit ginjal akibat penyakit DM dan merupakan penyebab gagal ginjal [13]. Kerusakan ginjal akibat stres oksidatif tersebut dapat diatasi dengan beberapa mekanisme pertahanan di ginjal, salah satunya melalui aktivitas enzim SOD [14].

Pengukuran aktivitas enzim SOD pada ginjal tikus putih dilakukan secara tidak langsung menggunakan metode NBT menggunakan spektrofotometer visibel secara kuantitatif. Prinsip pengukuran aktivitas enzim SOD adalah reduksi senyawa NBT oleh ion superoksida hasil reaksi senyawa xatin dan XOD. Pengukuran rata-rata aktivitas SOD ginjal tikus kontrol negatif (KN) yakni tikus dalam keadaan sehat menunjukkan nilai sebesar 3,4 U/mL. Aktivitas SOD pada tikus DM yang telah diterapi menunjukkan peningkatan. Sedangkan pada tikus kontrol positif DM tanpa terapi (KP), aktivitas SOD menurun menjadi 0,59 U/mL, hal ini diduga terkait dengan kadar glukosa darah yang meningkat.

Aktivitas SOD tikus sehat (KN) merupakan nilai acuan aktivitas SOD dalam keadaan normal, nilai aktivitas SOD ini terkait dengan kondisi metabolisme tubuh yang sehat dengan kadar radikal bebas normal. Ketika radikal bebas dalam tubuh meningkat, aktivitas SOD dalam tubuh juga meningkat untuk menangkal radikal bebas sehingga terjadi keseimbangan antara antioksidan dan radikal bebas. Hal ini tercermin pada pengukuran aktivitas SOD pada tikus DM yang diterapi dimana terjadi peningkatan aktivitas SOD melebih nilainya pada tikus normal. Hal ini juga mengkonfirmasi bahwa pada tikus DM yang diterapi terdapat jumlah radikal bebas yang meningkat dari keadaan tikus sehat, akan tetapi terapi infusa pekat buah pare berhasil menjaga aktivitas SOD yang sesuai dengan yang dibutuhkan oleh kondisi tubuh.

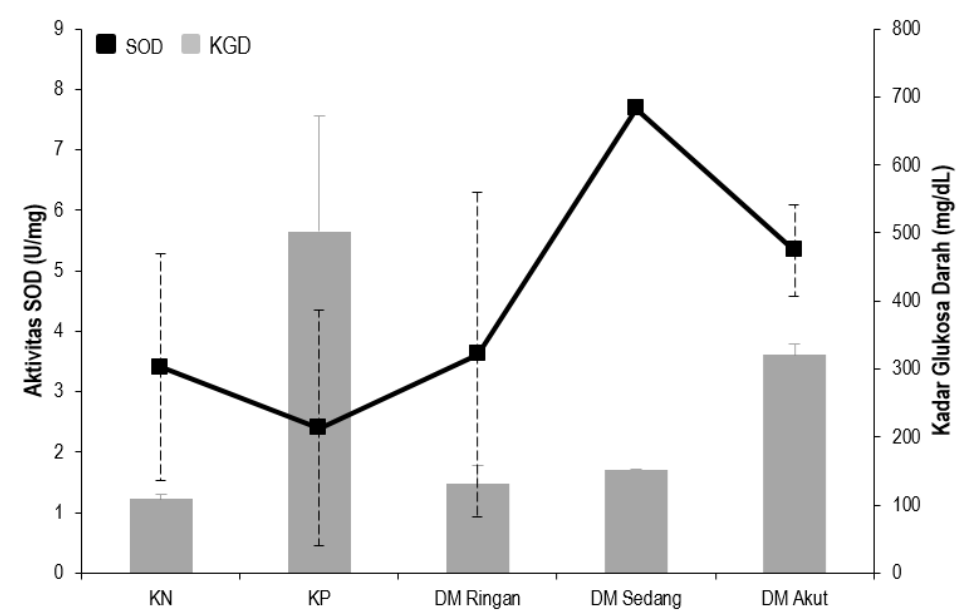

Gambar 3. Grafik hubungan KGD dengan aktivitas SOD pada tikus dengan tingkat DM yang berbeda. 
Aktivitas SOD yang terukur pada tikus menderita DM (KP) terjadi penurunan. Hal ini menunjukkan bahwa tubuh tidak mampu menyediakan jumlah aktivitas enzim SOD yang mencukupi untuk menetralkan jumlah radikal bebas yang meningkat akibat KGD yang tinggi. Pada beberapa penelitian menunjukkan bahwa aktivitas enzim SOD menurun ketika tubuh mengalami peningkatan kadar glukosa darah $[4,15,16]$. Grafik hubungan antara aktivitas SOD dan kadar glukosa darah dapat di lihat pada Gambar 3. Hasil perhitungan deskriptif menunjukkan bahwa aktivitas SOD ginjal tikus DM dengan terapi infusa pekat buah pare naik sebesar $144,76 \%$ dari keadaan tikus DM tanpa terapi.

Pengamatan lebih dalam terhadap pengaruh variasi dosis terapi pada aktivitas SOD tampak pada Gambar 4. Hasil uji normalitas data aktivitas SOD menghasilkan nilai $p>0,05$, dapat disimpulkan bahwa data berdistribusi normal. Pengujian One Way Anova pada data aktivitas SOD tikus DM dan yang diterapi didapatkan nilai $p$ (Sig.) kurang dari 0,05 $(0,001<0,05)$ dan nilai $F$ hitung $>F$ tabel $(5,59>2,66)$. Hasil menunjukkan perbedaan yang signifikan artinya terdapat pengaruh pemberian ekstrak infusa pekat buah pare terhadap aktivitas SOD ginjal tikus putih DM.

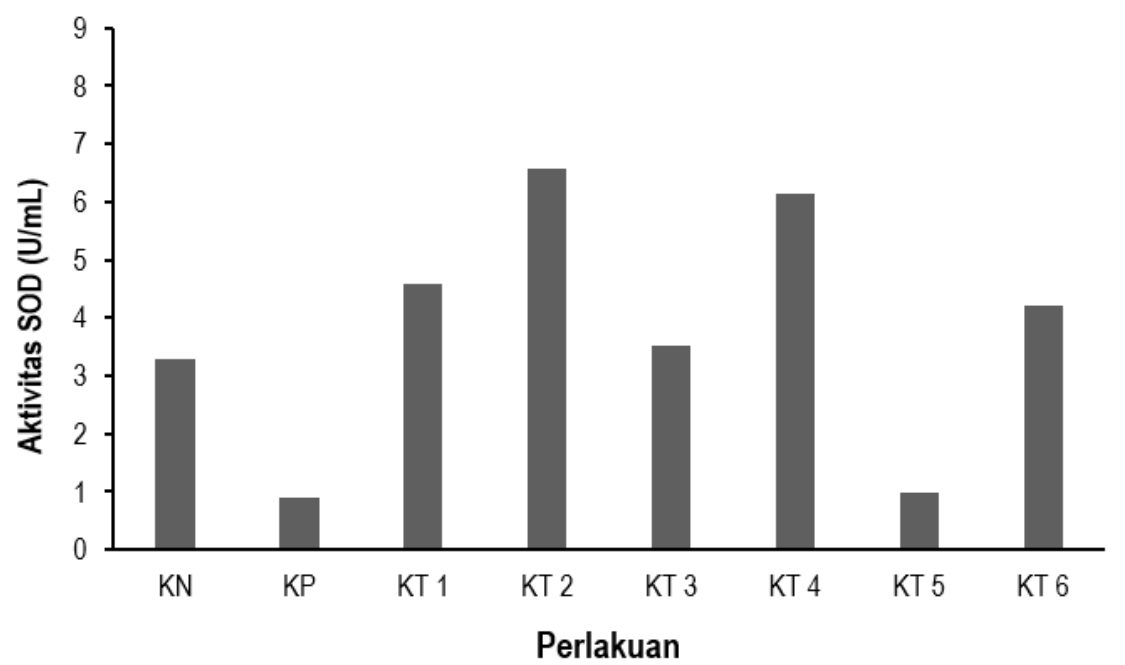

Gambar 4. Aktivitas SOD tikus yang diterapi infusa buah pare sesudah terapi $(\mathrm{H}-15) . \mathrm{KN}=$ kontrol normal, $\mathrm{KP}=$ kontrol positif, $\mathrm{KT} 1=$ dosis $0,15 \mathrm{~mL}, \mathrm{KT} 2=$ dosis $0,3 \mathrm{~mL}, \mathrm{KT} 3=$ dosis $0,45 \mathrm{~mL}, \mathrm{KT} 4=$ dosis $0,6 \mathrm{~mL}, \mathrm{KT} 5=$ dosis $0,8 \mathrm{~mL}, \mathrm{KT} 6=$ dosis $1 \mathrm{~mL}$.

Setelah uji ANOVA, dilakukan uji lanjut. Uji lanjut bertujuan untuk menguji perbedaan antar perlakuan dari hasil penelitian. Pada penelitian ini digunakan uji BNT atau uji LSD menggunakan SPSS. Uji LSD ini dijadikan acuan dalam menentukan apakah rata-rata beberapa perlakuan dalam hal ini adalah variasi dosis terapi berbeda secara statistik atau tidak. Untuk menghitung nilai LSD, digunakan data dari uji ANOVA yang telah dilakukan sebelumnya. Hasil yang diperoleh menunjukkan bahwa variasi dosis $0,3 \mathrm{~mL} / 200 \mathrm{~g} \mathrm{BB}$ merupakan satu-satunya dosis yang berbeda secara signifikan terhadap kontrol positif.

Berdasarkan hasil penelitian ini, ternyata dosis $0,3 \mathrm{~mL} / 200 \mathrm{~g}$ BB infusa pekat buah pare menghasilkan efek terapi terbaik dibandingkan dosis yang lain, baik ditinjau dari kemampuan penurunan kadar glukosa darah maupun peningkatan aktivitas SOD. Pada dasarnya dosis $0,3 \mathrm{~mL} / 200 \mathrm{~g}$ BB infusa pekat buah pare adalah dosis yang setara dengan dosis yang digunakan untuk terapi DM menggunakan obat glibenklamid [9]. Sehingga dapat disimpulkan bahwa terapi DM menggunakan infusa pekat buah pare memiliki kemampuan penurunan kadar glukosa darah yang setara dengan terapi obat medis standar.

\section{Kesimpulan}

Terapi ekstrak infusa pekat buah pare berpengaruh terhadap penurunan kadar glukosa darah dengan pemulihan seluruh tingkat diabetes mencapai KGD normal pada dosis $0,3 \mathrm{~mL} / 200 \mathrm{~g} \mathrm{BB}$ dan kemampuan penurunan kadar SOD ginjal tikus diabetes mellitus sebesar $144,76 \%$.

\section{Ucapan Terima Kasih}

Penulis mengucapkan terima kasih kepada seluruh pihak Penelitian Kompetitif Mahasiswa Fakultas Sains dan Teknologi Universitas Islam Negeri Maulana Malik Ibrahim Malang atas bantuan dana penelitian. 


\section{Daftar Pustaka}

[1] World Health Organization, "Definition, Diagnosis and Classification of Diabetes Mellitus and its Complications: Report of a WHO Consultation. Part 1, Diagnosis and Classification of Diabetes Mellitus," Geneva: World Health Organization, 1999. [Online]. Tersedia: https://apps.who.int/iris/handle/10665/66040. [Diakses 14 Februari 2018].

[2] H. Permana, "Komplikasi Kronik dan Penyakit Penyerta pada Diabetes," Hasan Sadikin Hospital, Bandung, 2009. [Online]. Tersedia: http://pustaka.unpad.ac.id/wp-content/uploads/2009/09/kompilasi_kronik_dan_penyakit_penyerta pada diabetesi.pdf. [Diakses 2 Agustus 2018].

[3] D. Priantono, W. Mulyawan, N.S. Hardiany, \& S.I. Wanandi, "Pengaruh Induksi Hipoksia Hipobarik Intermiten pada Aktivitas Spesifik Manganese Superoxide Dismutase dan Kadar Malondialdehyde Ginjal Tikus," eJournal Kedokteran Indonesia, vol. 1, no. 3, pp. 208-215, 2013.

[4] T. Wresdiyati, M. Astawan, \& V.D. Nurwati, "Level Antioksidan Superoksida Dismutase (SOD) Menurun pada Jaringan Ginjal Tikus Hiperkolesterolemia: Suatu Kajian Imunohistokimia," Jurnal Sain Veteriner, vol. 24, no. 2, pp. 168-176, 2006.

[5] P.L. Larasati, "Efek Penurunan Kadar Glukosa Darah Kombinasi Ekstrak Etanol Daun Alpukat (Persea americana Mill) dan Buah Oyong (Luffa acutangula (L.) Roxb) pada Mencit Putih Jantan yang Dibebani Glukosa," Skripsi, Fakultas Matematika Dan ILmu Pengetahuan Alam, Universitas Indonesia, Depok, 2012.

[6] T. Subahar, "Khasiat dan Manfaat Pare: Si Pahit Pembasmi Penyakit," Jakarta: Agro Media Pustaka, 2004.

[7] S. Darmawati, \& S.S. Dewi, "Efek Ekstrak Buah Pare (Momordica charantia, L) terhadap Zona Hambatan Pertumbuhan Salmonella typhi Penyebab Salmonellosis," Jurnal IImu Kesehatan Pengembangan IImu-IImu Kesehatan, vol. 1, no. 1, pp. 2008.

[8] I.K.A. Yuda, M.S. Athara, \& A.A.G.O. Dharmayudha, "Identifikasi Golongan Senyawa Kimia Ekstrak Etanol Buah Pare (Momordica charantia) dan Pengaruhnya terhadap Penurunan Kadar Glukosa Darah Tikus Putih Jantan (Rattus novergicus) yang Diinduksi Aloksan," Buletin Veteriner Udayana, vol. 5, no. 2, pp. 87-95, 2013.

[9] F.T. Pratama, "Pengaruh Decocta Buah Pare (Momordica charantia L.) terhadap Penurunan Kadar Glukosa Darah Tikus Wistar yang Diberi Beban Glukosa," Skripsi, Program Pendidikan Sarjana Kedokteran Fakultas Kedokteran, Universitas Diponegoro, Semarang, 2011.

[10] Kementerian Kesehatan RI, "Farmakope Indonesia Edisi V," Jakarta: Kementerian Kesehatan Republik Indonesia, 2014.

[11] S.P. Sari, Azizahwati, \& D.A. Ratimanjari, "Pengaruh Pembelian Infusa Herbal Sambiloto (Andrographis paniculata Ness) terhadap Glibenklamid dalam Menurunkan Kadar Glukosa Darah Tikus Putih Jantan yang Dibuat Diabetes," Pharmaceutical Sciences and Research, vol. 9, no. 1, pp. 1-11, 2011.

[12] American Diabetes Association (ADA), "Standards of Medical Care in Diabetes - 2012," Diabetes Care, vol. 35, no.1, pp. S11-S63, 2012.

[13] Murnah, \& K.S. Indranila, "Pengaruh Ekstrak Etanol Mengkudu (Morinda citrifolia L) terhadap Diabetik Nefropati pada Tikus Spraque Dawley yang Diinduksi Streptozotocin (STZ)," Diponegoro Journal of Nutrition and Health, vol. 2, no. 1, pp. 1-15, 2014.

[14] Y. Ding, Y. Li, M.C. Zimmeman \& H.D. Schultz, "Elevated Mitochondrial Superoxide Contributes to Enhanced Chemoreflex in Heart Failure Rabbits," American Journal of Physiology-Regulatory, Integrative and Comparative Physiology, vol. 298, no.2, pp. R303-R311, 2010.

[15] B. Lukiati, A. Aulani, \& W. Darmanto, "Profil Distribusi INOS dan Kadar NO Pankreas Tikus Diabetes Mellitus Hasil Induksi MLD-STZ Pasca Pemberian Ekstrak Etanol Temu Giring (Curcuma heyneana), Jurnal Kedokteran Hewan, vol. 6, no. 2, pp. 120-124, 2012.

[16] C. Retnaningsih, Darmono, B. Widianarko, \& S.F. Muis, "Peningkatan Aktivitas Superoksida Dismutase pada Tikus Hiperglikemi dengan Asupan Tempe Koro Benguk (Mucuna pruriens L.)," Jurnal Agritech, vol. 33, no. 2, pp. 154-161, 2013. 